\title{
Fabrication of transparent spinel by the reactive spark plasma sintering of spray-dried Magnesia- Alumina nanocomposite without sintering aid
}

F. Davar ( $\nabla$ davar@iut.ac.ir)

Isfahan University of Technology

Nasrin Heidari

Isfahan University of Technology

Amir Alhaji

Isfahan University of Technology

\section{Research Article}

Keywords: Magnesium aluminate, SPS, Reactive sintering, fracture toughness

Posted Date: August 25th, 2021

DOI: https://doi.org/10.21203/rs.3.rs-812277/v1

License: (c) (i) This work is licensed under a Creative Commons Attribution 4.0 International License.

Read Full License 


\section{Abstract}

In this project, magnesia-alumina composite granules were prepared using spray drying method. Next, the synthesized powder was sintered at $1400^{\circ} \mathrm{C}$ for $15 \mathrm{~min}$ under $100 \mathrm{MPa}$ pressure through spark plasma sintering without using any sintering aid. The effect of two sintering temperatures of $1400{ }^{\circ} \mathrm{C}$ and 1500 ${ }^{\circ} \mathrm{C}$ was explored on the phase formation, density, fracture toughness, and optical transmission within visible and IR ranges. SEM results indicated that the magnesia-alumina composite granules had spherical morphology with the mean particle size of 21 micrometers. The XRD pattern showed that after the spark plasma sintering stage at $1400^{\circ} \mathrm{C}$ and $1500{ }^{\circ} \mathrm{C}$, the spinel phase of magnesium aluminate was obtained as in situ. The disc sintered at $1400^{\circ} \mathrm{C}$ had greater maximum transmission compared to the samples sintered at $1500{ }^{\circ} \mathrm{C}(47 \%$ vs. $~ 70 \%)$ within the middle IR region because of lower porosity of the sample. The magnesium aluminate spinel sintered at $1400{ }^{\circ} \mathrm{C}$ had a density $99.98 \%$ of the theoretical density, hardness $18 \mathrm{GPa}$, and fracture toughness $1.6 \mathrm{MPam} 1 / 2$.

\section{Introduction}

Today, transparent polycrystalline ceramics play a significant role in developing advanced and novel technologies. These ceramics fulfill many demands across various areas including fabrication of scratchand chemical-resistant optical pieces, anti-abrasion as well as shockproof sheets and lenses, producing transparent armors, etc. [1-5].

Magnesia-aluminate spinel ceramic is an oxide transparent ceramic which covers a wide range of hightemperature applications because of its desirable properties. This ceramic is transparent because of optical convergence resulting from its crystalline structure within a wide range of electromagnetic radiation (2-5.5 micrometer). The unique features of this ceramic include high transparency and low absorption within the middle IR region, excellent mechanical properties, high hardness, resistance against thermal shock, chemical stability, plus average heat conductivity and heat expansion coefficient [6-9]. All these have caused this ceramic to be used in fabrication of sensors, probes, electro-optical imaging systems, optoelectronic devices such as solid state lasers, screens, night vision equipment, and light emitting diodes (LEDs). Magnesia-aluminate spinel ceramic is a well-known ceramic in military uses, including transparent infrared windows, transparent armors, and transparent traps [1, 10-14].

In order to fabricate magnesia-aluminate spinel transparent ceramic, typically various sintering methods such as HP, HIP, SPS, and in situ sintering are used $[1,8,10-12,16-18]$. Nevertheless, most commercial productions of this ceramic occur through HP and HIP. Usage of these methods is costly, causes grain growth, causing diminished mechanical properties of the final ceramics $[3,12,19]$. Various researchers have used spark plasma sintering methods for fabricating transparent ceramics. This is because by constraining the grain growth and obtaining a uniform distribution of the grain size, it is possible to achieve almost complete density within a short period of time $[11,20]$. 
The morphology plays a significant role in the fabrication of magnesia-aluminate spinel transparent ceramic. Spray-drying is a popular method for synthesizing powders with uniform particle size distribution and high flowability [27]. Sparse studies have been performed with regards to the synthesis of magnesia-aluminate spinel using spray drying method $[14,27,28]$.

In order to achieve $\mathrm{MgAl}_{2} \mathrm{O}_{4}$ granules, Kanrava et al. prepared magnesia-aluminate spinel granules using $\mathrm{MgO}$ and $\mathrm{Mg}(\mathrm{OH})_{2}$ as precursors of $\mathrm{Mg}$ and $\mathrm{Al}_{2} \mathrm{O}_{3}$ plus $\mathrm{AlO}(\mathrm{OH})$ as the precursors of $\mathrm{Al}$ [14].

In the research by Alhaji et al., they explored the effect of spinel - LiF ( LiF as a sintering aid) granules on the optical transparency of the final ceramic. The samples prepared through the granulation process had maximum optical transmission (70\%) at the wavelength 2.5-5 micrometer. This group indicated that the in-line optical transmission of the granulated sample was greater than that of the non-granulated samples. Thus, granulation would improve the optical properties of the final piece [28]. Elsewhere, Waetzig et al. achieved spinel bulk through reactive sintering method via hot press device with $4.2 \% \mathrm{LiF}$ sintering aid and magnesia-alumina nanocomposite precursors at the sintering temperature of $1650^{\circ} \mathrm{C}$. The group achieved theoretical spinel transmission at the wavelength of about $600 \mathrm{~nm}$. IR transmission of the spinel sample obtained by Waetzig group has not been reported [2].

In this project, magnesia-aluminate spinel transparent disc was obtained through spark plasma sintering without using any sintering aid from magnesia-aluminate nanocomposite granules. Next, the effect of sintering temperature was tested on the phase formation, microstructure, and transparency of the final magnesia-aluminate spinel ceramic.

\section{Materials And Methods \\ 2.1 materials}

Aluminum oxide $\left(\mathrm{Al}_{2} \mathrm{O}_{3} 99.99 \%, 150 \mathrm{~nm}\right)$ magnesium oxide ( $\mathrm{MgO} 99.99 \%, 50 \mathrm{~nm}$ ) were purchased from US nano Company, ammounium poly methyl acrylate (Dolapix CE64), poly vinyl alcohol $\left(P V A\left(\mathrm{C}_{2} \mathrm{H}_{4} \mathrm{O}\right)-\right.$ $99 \%$, Molecular weigth $=10000$ ) were purchased from Zschimmer \& Schwarz and Merck Co., respectively.

\subsection{Suspension preparation}

In order to prepare suspension with suitable stability, first proper amounts of magnesium oxide and aluminum oxide nanoparticles (according to the magnesia-aluminate spinel stoichiometric ratio) were mixed with $1 \mathrm{wt} \%$ of polyvinyl alcohol (as a binder) and $1 \mathrm{wt} \%$ of Dolapix CE64 (as a dispersing agent) with $150 \mathrm{ml}$ water. The resulting suspension was exposed to ultrasound waves for $15 \mathrm{~min}$ with the divorce power $60 \mathrm{~W}$, on/off cycle ratio of 50/10s. The ultrasound device used was ultrasonic (TOPSONICS model, Iran) with frequency of $20 \mathrm{kHz}$ and power of $400 \mathrm{~W}$. Eventually, the resulting suspension was placed on a stirrer at room temperature for a specific period of time so that a stable suspension would form. The $\mathrm{pH}$ of the suspension in this state was 9.

\subsection{Spray dryer}


Spray dryer device LabPlant SD Basic FT30MKIII was used (Keison products, Chelmsford, Essex, UK). The spray dryer parameters included atomizer rate $8000 \mathrm{rpm}$, input air temperature $150^{\circ} \mathrm{C}$, and output air temperature $95^{\circ} \mathrm{C}$, plus $3 \mathrm{ml} / \mathrm{min}$ rate. The prepared granulated powders were heated at $500^{\circ} \mathrm{C}(\mathrm{NCR}-\mathrm{HT}$ 2200 furnace, Nik Ceram Razl Co.) with the $1^{\circ} \mathrm{C} / \mathrm{min}$ rate for $12 \mathrm{~h}$ so that the polymeric binder would be eliminated.

\subsection{Spark plasma sintering}

For the sintering process, SPS device (SPS 60 ton-10KA, Malek Ashtar University of Technology, Iran) was employed. Briefly, $1.5 \mathrm{~g}$ of the granulated powder was poured into a graphite mold. Then, the sample was sintered at 1500 and $1400^{\circ} \mathrm{C}$ under $100 \mathrm{Mpa}$ pressure for $15 \mathrm{~min}$. Figure 1 indicates the SPS cycle utilized in this method for $1500^{\circ} \mathrm{C}$. The thermal and pressure cycle of SPS along with the temperature and pressure elevation rate of the samples sintered at $1400^{\circ} \mathrm{C}$ is also similar to Fig. 1 , with the difference that the final temperature had been $1400^{\circ} \mathrm{C}$ instead of $1500^{\circ} \mathrm{C}$.

\subsection{Characterization methods}

Fourier transform infrared (FT-IR) spectra were recorded with a disc made of $\mathrm{KBr}$ using a spectrophotometer device (680-PLUS, JASCO Co.) within $400-4000 \mathrm{~cm}^{-1}$. In order to detect the formed phases, X-ray diffraction test was performed using XRD device (X-Pert-MPD, Phillips company). XRD test was conducted using monochromatic beam Cu ka with wavelength $1.5046 \AA$ at voltage $40 \mathrm{kV}$ and current of $30 \mathrm{~mA}$. The diffraction was performed within the $2 \theta$ range of $10-80^{\circ}$ with step size of $0.05^{\circ} \mathrm{C}$ and time per step of $1 \mathrm{~s}$. The field emission scanning electron microscopy (FE-SEM) were recorded using FEl device equipped with energy dispersive X-ray spectroscopy. In order to characterize the dimensions and morphology of the submicron powders, scanning electron microscope (JEO 6510) was used. The particle size distribution histogram was obtained by investigating the size of 200 particles in FE-SEM images.

The linear transmission was measured within 2.5-10 micron using Fourier transform spectrophotometer device (FTIR-8400S, Shimadzu, Japan). The visible transmission spectra were captured through SHIMADZU VIS-NIR Spectrophotometer 3100-Japan. Finally, the hardness of the samples was measured via Vickers hardness measurement method (HM-200, MITUTOYO, Japan).

\section{Results And Discussion}

Figure 2a displays the SEM images of the samples after the spray drying stage. The morphology of the granules is spherical with size of 3-50 micron. The mean particle size of these granules is 21 micrometers. The high magnification of granules (Fig. 2b) shows that it composed of very fine particles with average size of less than $100 \mathrm{~nm}$. Figure 3 reveals the EDS analysis of the granules after the debinding process. Elements of aluminum, magnesium, and oxygen exist in this analysis, while the binder carbon has been removed from the sample after the calcination process at $500^{\circ} \mathrm{C}$ for $12 \mathrm{~h}$. Figure 4 reveals the X-ray map of the granulated powders. Uniform distribution of aluminum, magnesium, and oxygen suggests formation of magnesia-alumina composite with uniform distribution of these elements. 
Figure 5 indicates the XRD pattern of the final powder after heating at $500^{\circ} \mathrm{C}$ for $12 \mathrm{~h}$. It is observed that Alpha-alumina phrases with rhombohedral crystalline network plus cubic phase of magnesia exist in the XRD pattern of composite granule.

Figure 6-a displays the FTIR spectrum of the granulated powder prepared using spray drying method before calcination step (S). According to the figure, the wide band at $3448 \mathrm{~cm}^{-1}$ belongs to the stretching vibrations of $\mathrm{OH}$ group, which can be associated with hydroxyl groups in the sample and large amounts of water in the sample. The vibrations observed at $2857 \mathrm{~cm}^{-1}$ and $2925 \mathrm{~cm}^{-1}$ indicate symmetric and asymmetric stretching vibrations of the $-\mathrm{CH}_{2}$ group related to PVA binder. The absorption band at 1727 $\mathrm{cm}^{-1}$ is related to stretching vibrations of the $-\mathrm{C}=0$ group related to ammonium polyacrylate (Dolapix Ce64). The absorption band at $1631 \mathrm{~cm}^{-1}$ is related to bending vibrations of the water molecule, while those observed at $1374 \mathrm{~cm}^{-1}$ and $1459 \mathrm{~cm}^{-1}$ are related to bending vibrations of alkane $-\mathrm{CH}$. The peaks at $1000-1300 \mathrm{~cm}^{-1}$ are associated with stretching vibrations of the C-O group. The bands at $400-1000$ $\mathrm{cm}^{-1}$ are related to the vibrations of the metal oxygen network (M-O). After powder heating at $500^{\circ} \mathrm{C}$ for $12 \mathrm{~h}$, the stretching bands related to polyvinyl alcohol polymer binder and Dolapix Ce64 dispersing agent were removed, and only metal oxide vibrating bands are observed (Fig. 6b).

In order to investigate the effect of sintering temperature on the optical properties of the final magnesiaaluminate spinel ceramic, the granulated powders were sintered at $1500^{\circ} \mathrm{C}$ and $1400^{\circ} \mathrm{C}$ for $15 \mathrm{~min}$. Figure $7 a$ and $b$ indicate the XRD pattern of the fabricated bulks through the spark plasma sintering. As observed in the patterns, the magnesia-aluminate spinel phase has formed as fully single phase, while the peaks related to alumina and magnesia in the primary powders have been removed, suggesting completion of spinel phase formation at both of these sintering temperatures.

Figure 8 reveals the FE-SEM images of the fracture cross-sectional of the sintered disc of granulated powder at $1500^{\circ} \mathrm{C}$ and $1400^{\circ} \mathrm{C}$. According to this figure, intergranular porosity has decreased clearly with reduction of sintering temperature from $1500^{\circ} \mathrm{C}$ to $1400^{\circ} \mathrm{C}$. The relative density of the magnesiaaluminate spinel bulks was measured using Archimedes method. The spinel bulk density prepared at 1500 and $1400^{\circ} \mathrm{C}$ was obtained as $99.3 \%$ and $99.98 \%$ of the spinel theoretical density, respectively.

Figure $9 a$ and $b$ indicate the in-line transmission of the samples sintered through spark plasma sintering with $4 \mathrm{~mm}$ thickness. The maximum transmission obtained in this research was $70 \%$ in 2-5 micron region for the samples sintered at $1400^{\circ} \mathrm{C}$. This value of $\mathrm{IR}$ transmission was $25 \%$ greater than the in-line transmission of the samples sintered at $1500^{\circ} \mathrm{C}$. Visible transparency of the sample sintered at $1400^{\circ} \mathrm{C}$, according to Fig. 10, were again higher than those of the sample SPSed at $1500^{\circ} \mathrm{C}$. The lower transmission of the samples sintered at $1500^{\circ} \mathrm{C}$ is related to light scattering resulting from differences in the spinel refractive index and the air in the intergranular porosity in this sample. The transparency of current research was lower than other reports [3-7] due to higher thickness of spinel disc in this research and lower pressures of SPS (70 MPa in this work and higher than $100 \mathrm{MPa}$ for other works $[1-3,16,23])$. 
The hardness of the spinel samples sintered at $1500^{\circ} \mathrm{C}$ and $1400^{\circ} \mathrm{C}$ was obtained as 17 and $18 \mathrm{GPa}$, respectively. Figure 10 displays the effect of Vickers hardness test with $1 \mathrm{~kg}$ load $(P=10 \mathrm{~N})$ on the sintered samples. Given the length of the crack (C parameter) measured in the SEM images, the fracture toughness $\left(\mathrm{K}_{1 \mathrm{C}}\right)$ was obtained as 1.3 and $1.6 \mathrm{Mpam}^{1 / 2}$ using the crack length direct measurement method (Eq. 1). In Eq. 1, Young modulus of the spinel was considered $259 \mathrm{GPa}$ according to Ref. [20].

\section{$\mathrm{K}_{\mathrm{IC}}=0.016(\mathrm{E} / \mathrm{H})^{1 / 2} \times\left(\mathrm{P} / \mathrm{C}^{3 / 2}\right)$}

\section{Conclusion}

In this project, spherical magnesia-alumina composite granules were prepared with the mean particle size 21 micron using spray drying method of magnesia-aluminate nanoparticle suspension and 1 weight\% of dispersing agent Dolapix Ce64 plus PVA as an adhesive. Once these granules were heated at $500^{\circ} \mathrm{C}$ for $12 \mathrm{~h}$, the binder and dispersing agent were eliminated from the sample. After sintering of the resulting powder through SPS method for 15 min under $100 \mathrm{MPa}$ pressure at $1500^{\circ} \mathrm{C}$ and $1400^{\circ} \mathrm{C}$, magnesiaaluminate spinel transparent ceramic was obtained. The percentage of transparency in the middle IR region for the samples sintered at $1400^{\circ} \mathrm{C}$ was greater than at $1500^{\circ} \mathrm{C}$. This is due to the lower porosity of the sample sintered at $1400^{\circ} \mathrm{C}$. The fracture toughness and hardness of sample sintered at $1400^{\circ} \mathrm{C}$ showed $60 \%$ and 1.2 times improvement over the sample SPSed at $1500^{\circ} \mathrm{C}$ respectively. Generally, this method is suitable and convenient for in-situ fabrication of magnesium aluminate spinel without using any sintering aids.

\section{Declarations}

\section{Acknowledgment:}

The authors thank the Iran National Science Foundation (grant number 96013714) for its financial support of this research.

\section{References}

1. Zegadi, A., Kolli, M., Hamidouche, M. \& Fantozzi, G. Transparent $\mathrm{MgAl}_{2} \mathrm{O}_{4}$ spinel fabricated by spark plasma sintering from commercial powders. Ceram. Int. 44, 18828-18835 (2018).

2. Waetzig, Katja, and Thomas Hutzler. "Highest UV-vis transparency of $\mathrm{MgAl}_{2} \mathrm{O}_{4}$ spinel ceramics prepared by hot pressing with LiF."Journal of the European Ceramic Society37, no. 5, 2259-2263 (2017).

3. Ganesh, I. A review on magnesium aluminate $\left(\mathrm{MgAl}_{2} \mathrm{O}_{4}\right)$ spinel: synthesis, processing and applications. Int. Mater. Rev. 58, 63-112 (2013). 
4. Khaidukov, N. M., Brekhovskikh, M. N., Kirikova, N. Y., Kondratyuk, V. A. \& Makhov, V. N. Luminescence of $\mathrm{MgAl}_{2} \mathrm{O}_{4}$ and $\mathrm{ZnAl}_{2} \mathrm{O}_{4}$ spinel ceramics containing some 3d ions. Ceram. Int. 46, 21351-21359 (2020).

5. Kato, T., Nakauchi, D., Kawaguchi, N. \& Yanagida, T. Optical, scintillation, and dosimetric properties of dy-doped $\mathrm{MgAl}_{2} \mathrm{O}_{4}$ transparent ceramics. Optik (Stuttg). 207, 164433 (2020).

6. Xiao, Z. et al. Materials development and potential applications of transparent ceramics: A review. Mater. Sci. Eng. R Reports 139, 100518 (2020).

7. Benitez, T., Y. Gómez, S., de Oliveira, A. P. N., Travitzky, N. \& Hotza, D. Transparent ceramic and glassceramic materials for armor applications. Ceram. Int. 43, 13031-13046 (2017).

8. Bonnefont, G., Fantozzi, G., Trombert, S. \& Bonneau, L. Fine-grained transparent $\mathrm{MgAl}_{2} \mathrm{O}_{4}$ spinel obtained by spark plasma sintering of commercially available nanopowders. Ceram. Int. 38, 131-140 (2012).

9. Pappas, J. M. \& Dong, X. Porosity characterization of additively manufactured transparent $\mathrm{MgAl}_{2} \mathrm{O}_{4}$ spinel by laser direct deposition. Ceram. Int. 46, 6745-6755 (2020).

10. Balabanov, S. S. et al. Fabrication of transparent $\mathrm{MgAl}_{2} \mathrm{O}_{4}$ ceramics by hot-pressing of sol-gel-derived nanopowders. Ceram. Int. 41, 13366-13371 (2015).

11. Azizi-Malekabadi, M. \& Sarraf-Mamoory, R. Devising a novel method of producing high transparent magnesium aluminate spinel $\left(\mathrm{MgAl}_{2} \mathrm{O}_{4}\right)$ ceramics body using synthesized LiF nanopowder and spark plasma sintering. Mater. Chem. Phys. 250, 123035 (2020).

12. Liu, Y. \& Zhu, J. Fabrication of transparent $\mathrm{MgAl}_{2} \mathrm{O}_{4}$ ceramics by gelcasting and cold isostatic pressing. Ceram. Int. 46, 4154-4158 (2020).

13. Li, Q. et al. Study on the optical spectra of $\mathrm{MgAl}_{2} \mathrm{O}_{4}$ with oxygen vacancies. Mater. Technol. 00, 1-7 (2020).

14. Kanerva, U., Suhonen, T., Lagerbom, J. \& Levänen, E. Evaluation of crushing strength of spray-dried $\mathrm{MgAl}_{2} \mathrm{O}_{4}$ granule bedsha. Ceram. Int. 41, 8494-8500 (2015).

15. Shahbazi, H. \& Tataei, M. Influence of porosity on transparency behavior of $\mathrm{MgAl}_{2} \mathrm{O}_{4}$ spinel, experiment vs Mie theory. Opt. Mater. (Amst). 90, 289-299 (2019).

16. Zhang, P. et al. Aqueous gelcasting of the transparent $\mathrm{MgAl}_{2} \mathrm{O}_{4}$ spinel ceramics. J. Alloys Compd. 646 , 833-836 (2015).

17. Esposito, L., Piancastelli, A. \& Martelli, S. Production and characterization of transparent $\mathrm{MgAl}_{2} \mathrm{O}_{4}$ prepared by hot pressing. J. Eur. Ceram. Soc. 33, 737-747 (2013). 
18. Mroz, T., Goldman, L. M., Gledhill, A. D., Li, D. \& Padture, N. P. Nanostructured, infrared-transparent magnesium-aluminate spinel with superior mechanical properties. Int. J. Appl. Ceram. Technol. 9, 83-90 (2012).

19. Kim, J. M. et al. Fabrication of transparent $\mathrm{MgAl}_{2} \mathrm{O}_{4}$ spinel through homogenous green compaction by microfluidization and slip casting. Ceram. Int. 41, 13354-13360 (2015).

20. Morita, K., Kim, B.-N., Hiraga, K. \& Yoshida, H. Fabrication of transparent $\mathrm{MgAl}_{2} \mathrm{O}_{4}$ spinel polycrystal by spark plasma sintering processing. Scr. Mater. 58, 1114-1117 (2008).

21. Morita, K., Kim, B. N., Yoshida, H., Hiraga, K. \& Sakka, Y. Influence of pre- and post-annealing on discoloration of $\mathrm{MgAl}_{2} \mathrm{O}_{4}$ spinel fabricated by spark-plasma-sintering (SPS). J. Eur. Ceram. Soc. 36, 2961-2968 (2016).

22. Morita, K., Kim, B. N., Yoshida, H., Hiraga, K. \& Sakka, Y. Influence of spark plasma sintering (SPS) conditions on transmission of $\mathrm{MgAl}_{2} \mathrm{O}_{4}$ spinel. J. Am. Ceram. Soc. 98, 378-385 (2014).

23. Talimian, A., Pouchly, V., El-Maghraby, H. F., Maca, K. \& Galusek, D. Transparent magnesium aluminate spinel: Effect of critical temperature in two-stage spark plasma sintering. J. Eur. Ceram. Soc. 40, 24172425 (2020).

24. Pourshamsi, A., Alhaji, A. \& Emadi, R. The effect of pre-annealing and post-annealing on the transparency of $\mathrm{MgAl}_{2} \mathrm{O}_{4}$, prepared by slip casting and spark plasma sintering (SPS). Ceram. Int. 45, 7151-7156 (2019).

25. Morita, K., Kim, B. N., Yoshida, H., Hiraga, K. \& Sakka, Y. Distribution of carbon contamination in $\mathrm{MgAl}_{2} \mathrm{O}_{4}$ spinel occurring during spark-plasma-sintering (SPS) processing: I - Effect of heating rate and post-annealing. J. Eur. Ceram. Soc. 38, 2588-2595 (2018).

26. Wang, C. \& Zhao, Z. Transparent $\mathrm{MgAl}_{2} \mathrm{O}_{4}$ ceramic produced by spark plasma sintering. Scr. Mater. 61, 193-196 (2009).

27. Loghman-Estarki, M. R. et al. From sub-microsized $\mathrm{MgAl}_{2} \mathrm{O}_{4}$ powder to $\mathrm{MgAl}_{2} \mathrm{O}_{4}-\mathrm{Si}_{3} \mathrm{~N}_{4}$ nanocomposite powder by spray drying of ultrasonicated suspensions. Ceram. Int. 43, 12781-12788 (2017).

28. Alhaji, A., Taherian, M. H., Ghorbani, S. \& Sharifnia, S. A. Development of synthesis and granulation process of $\mathrm{MgAl}_{2} \mathrm{O}_{4}$ powder for the fabrication of transparent ceramic. Opt. Mater. (Amst). 98, 109440 (2019).

\section{Figures}




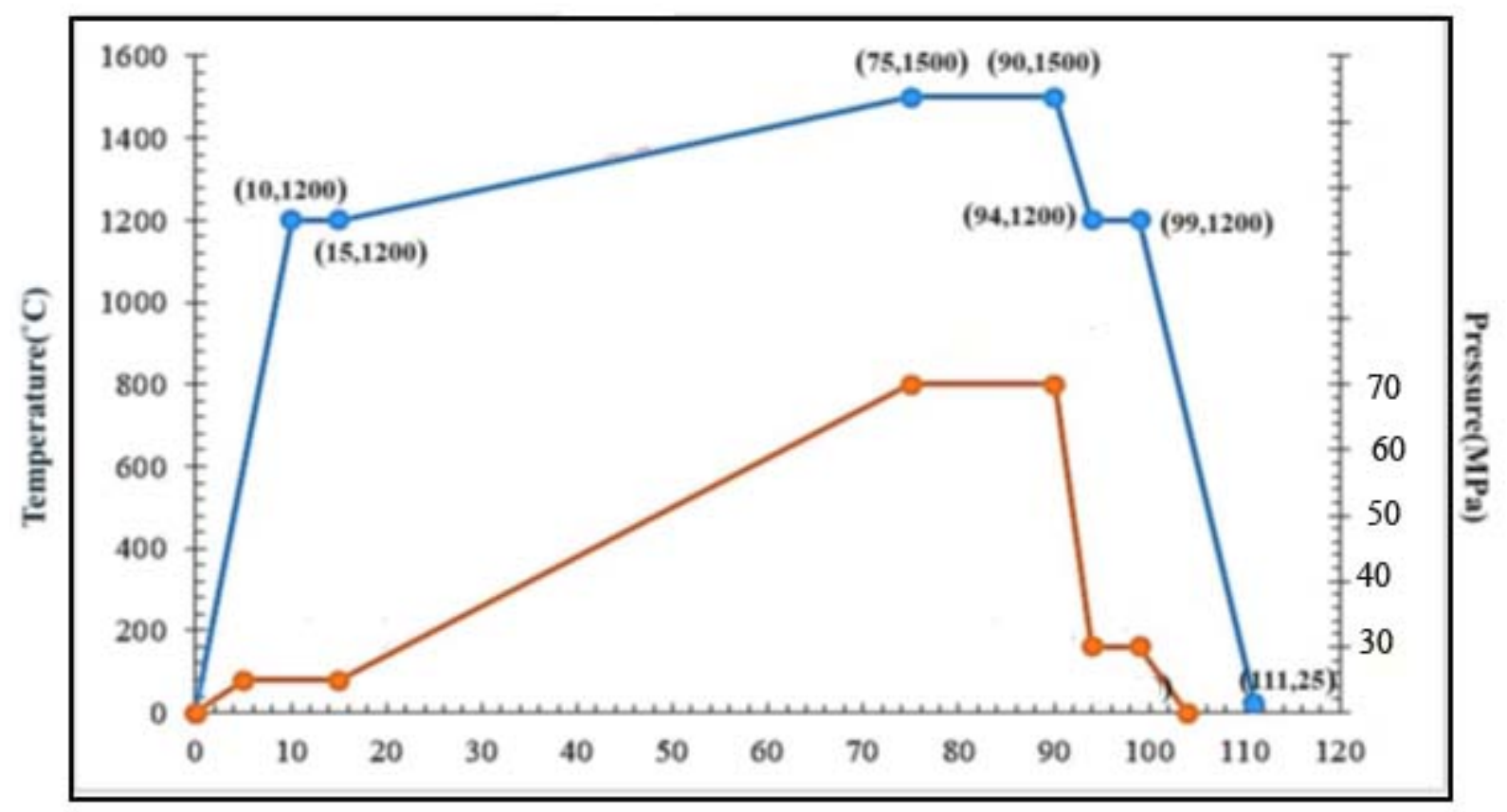

Figure 1

SPS cycle used to fabricate the transparent spinel disc

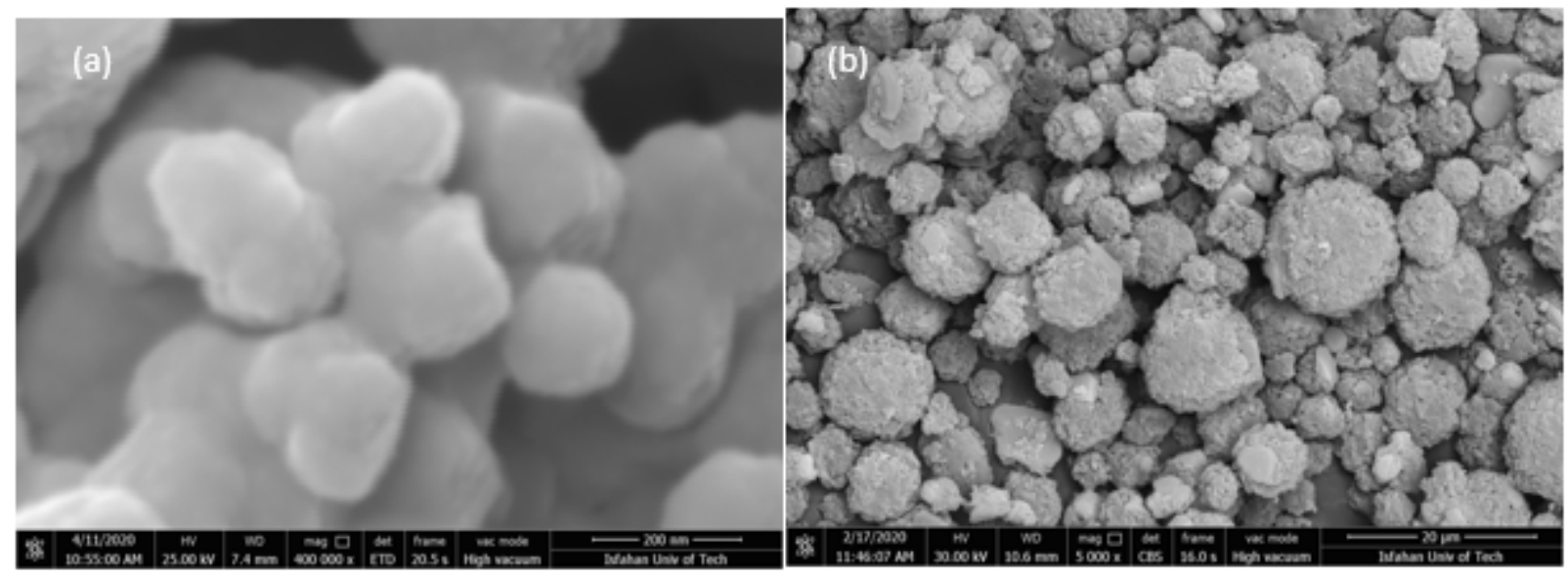

(c)



Figure 2 
a,b) FE-SEM images of the granules obtained via a spray drying method, and Fig. 2c) the particle size distribution histogram of these granules

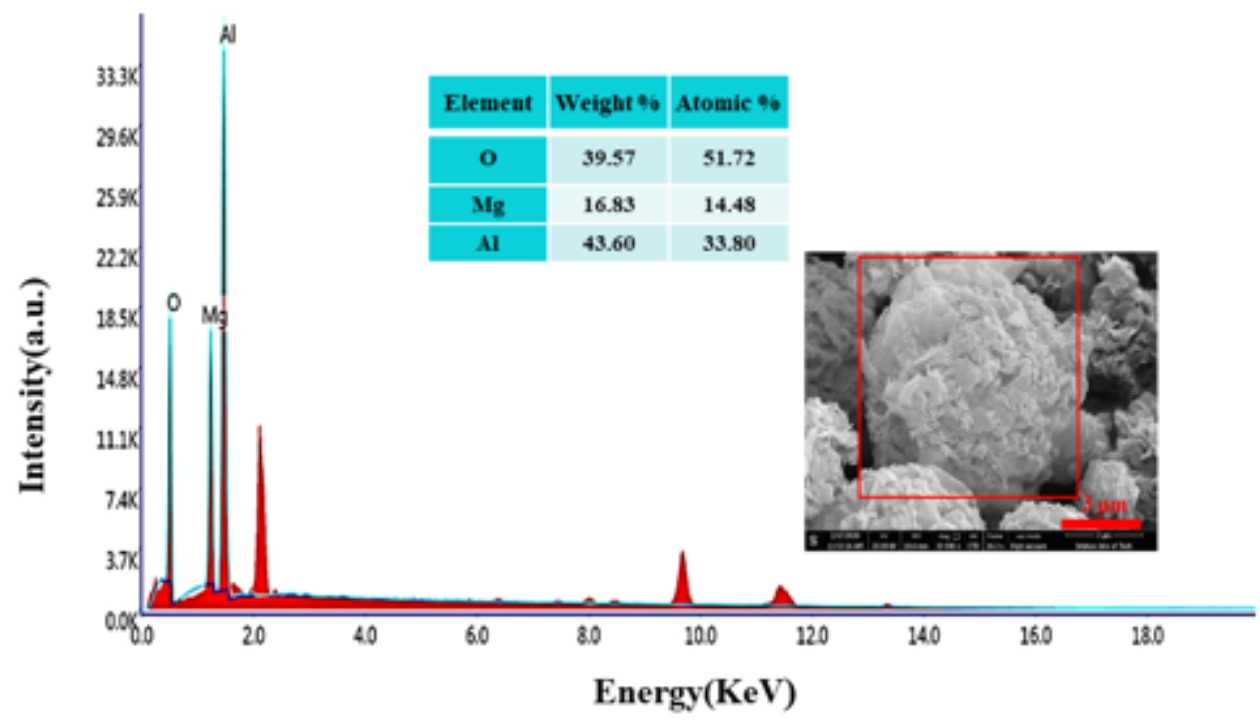

Figure 3

Energy dispersive X-ray spectroscopy analysis of the granules fabricated using spray drying method
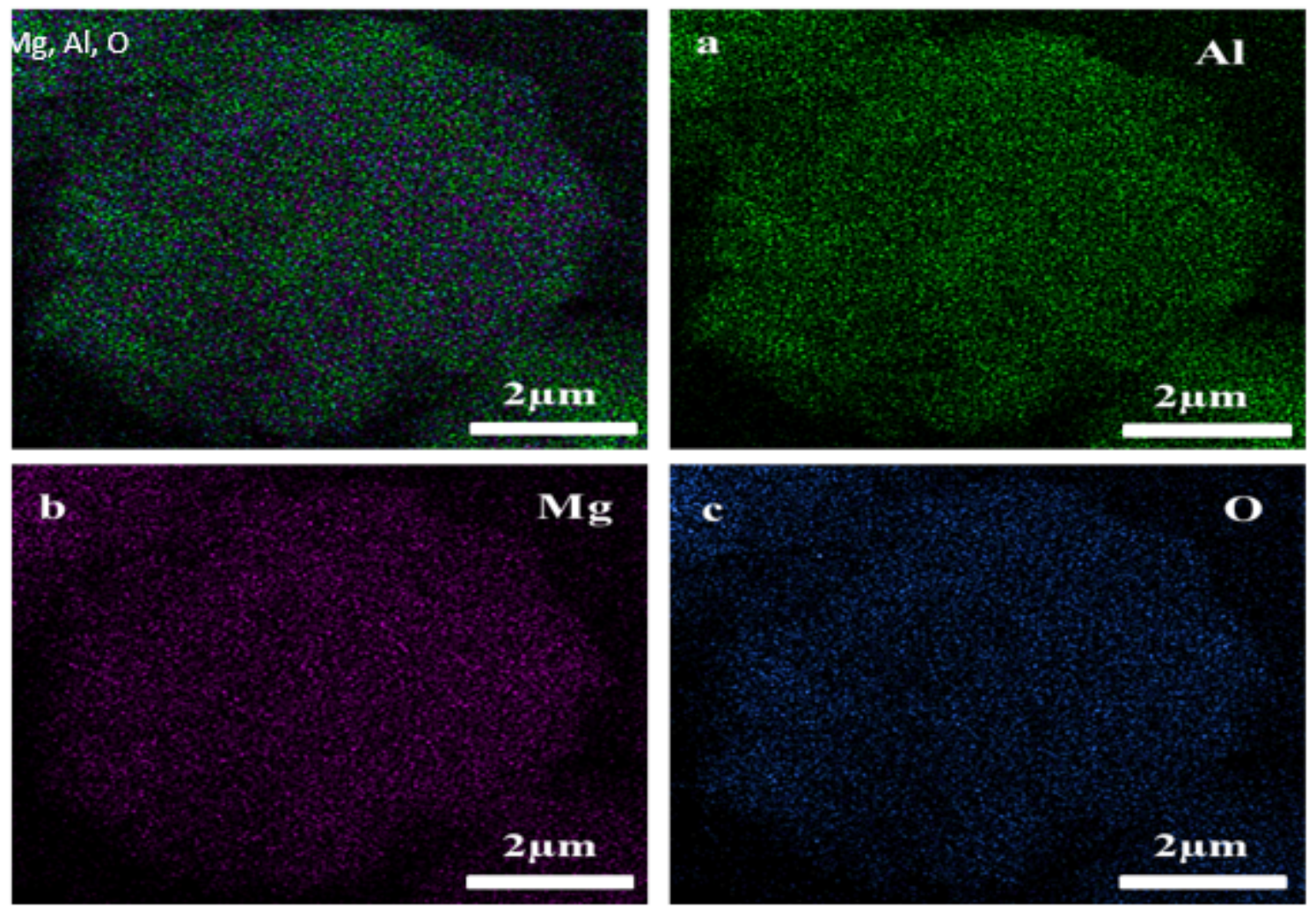

Figure 4

Elemental X-ray mapping analysis of a) $\mathrm{Al}, \mathrm{b}) \mathrm{Mg}$, and c) $\mathrm{O}$ of the granules 


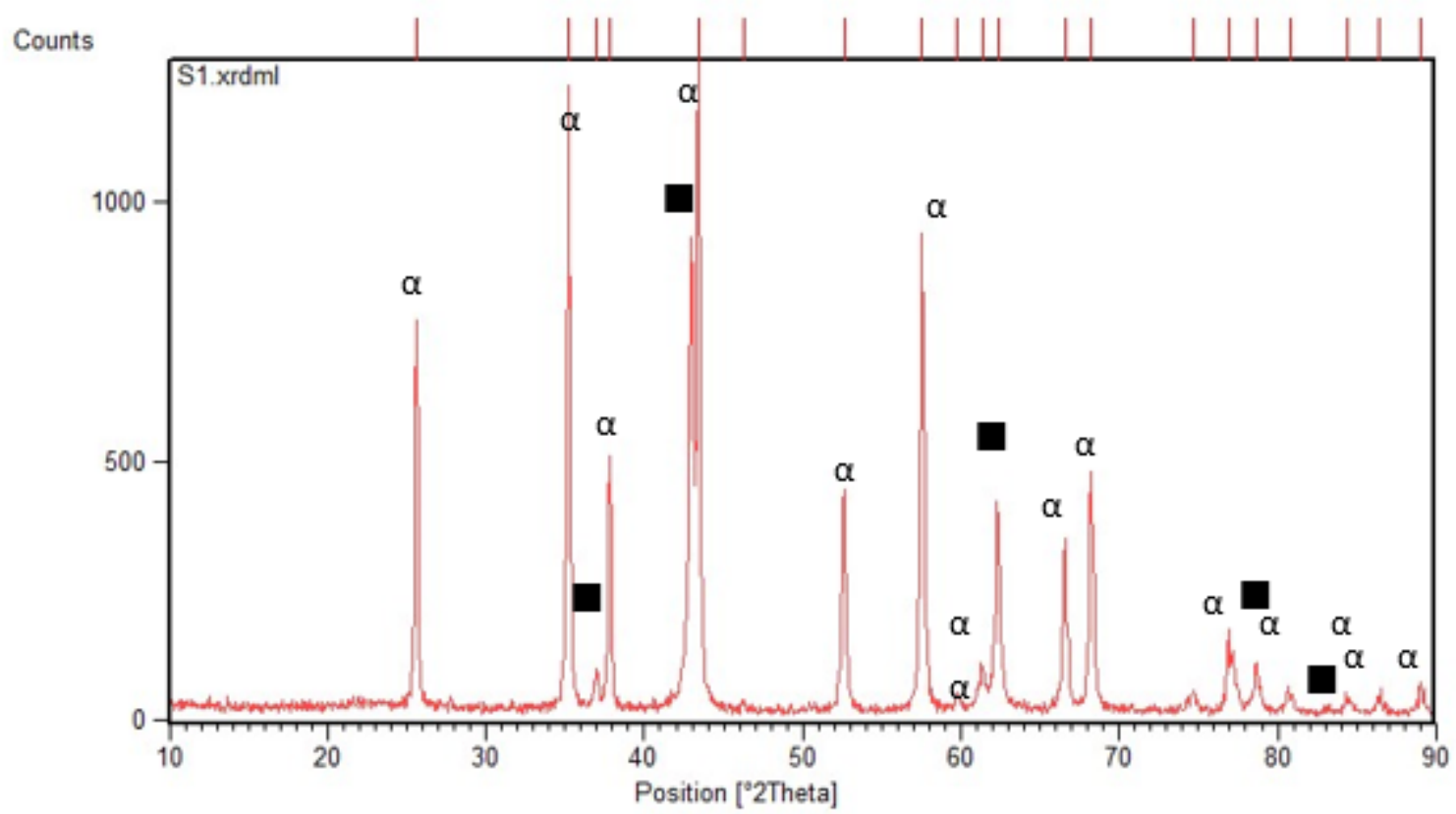

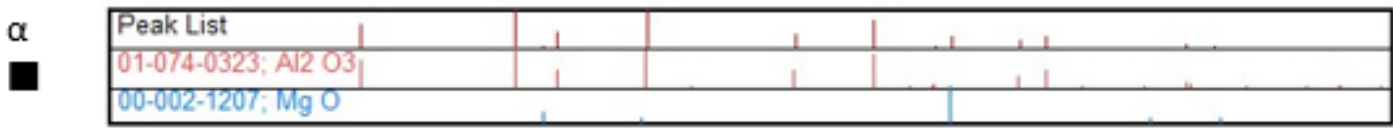

Figure 5

XRD pattern of the samples obtained via spray drying methods calcinated at $500{ }^{\circ} \mathrm{C}$ 
A

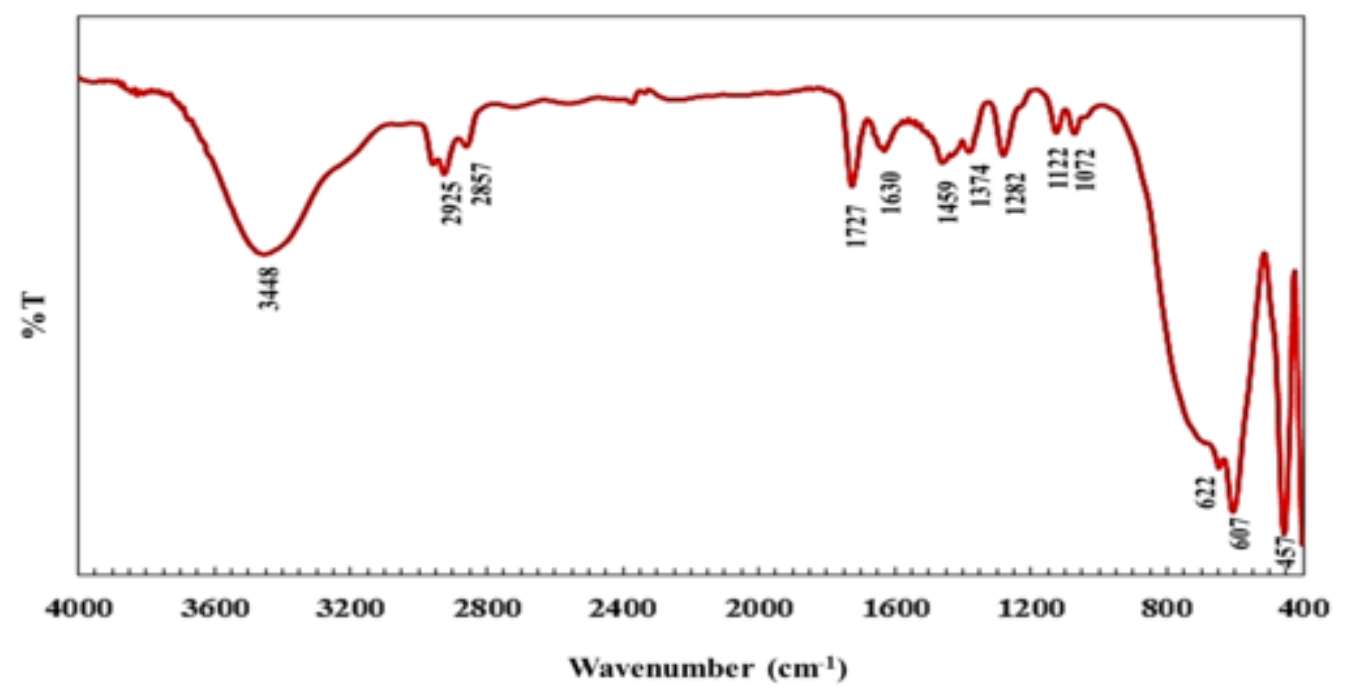

B

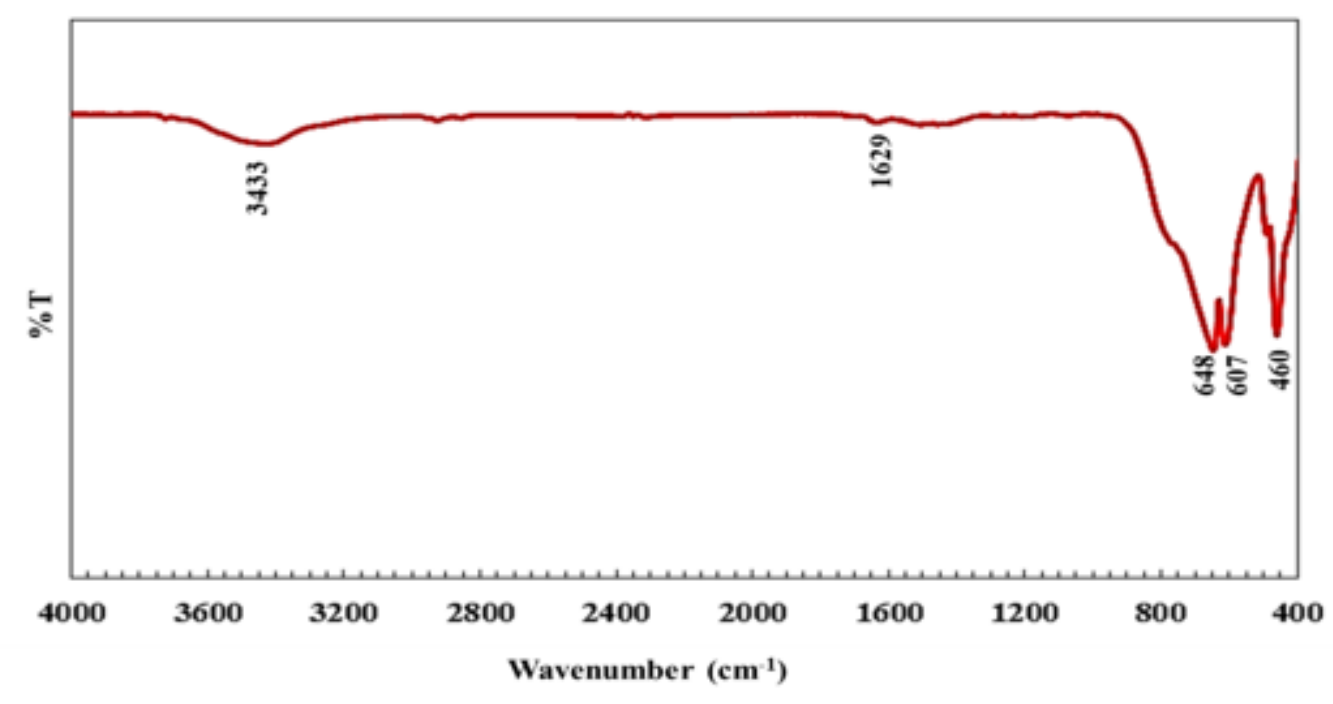

Figure 6

a. FT-IR spectrum of the granulated powder before calcination step b. FT-IR spectrum of the powder calcinated at $500^{\circ} \mathrm{C}$ for $12 \mathrm{~h}$ 

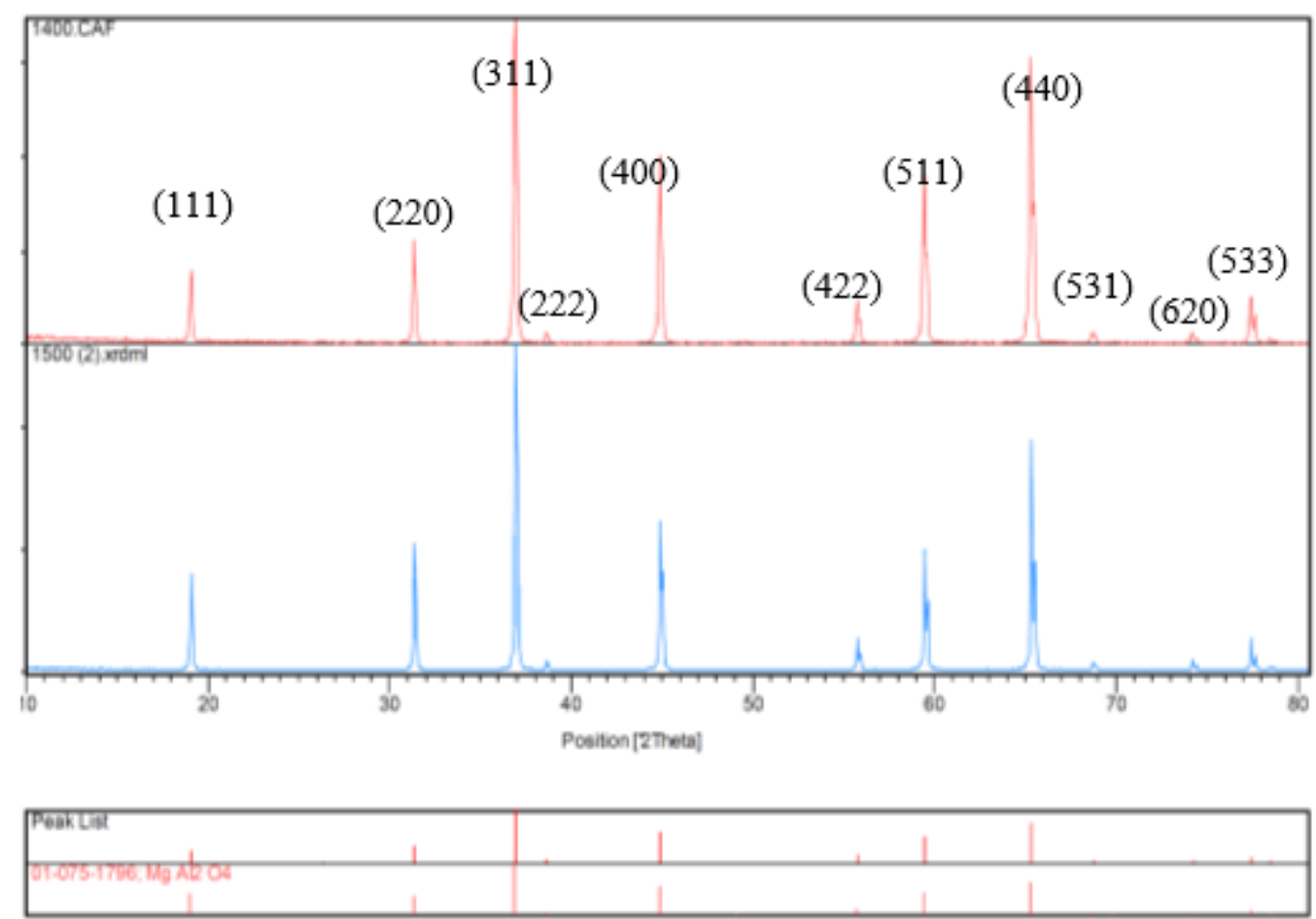

Figure 7

The XRD pattern of the spinel bulk prepared using powder, granulated via SPS method at $1400^{\circ} \mathrm{C}$ (red pattern) and $1500^{\circ} \mathrm{C}$ (blue pattern) 

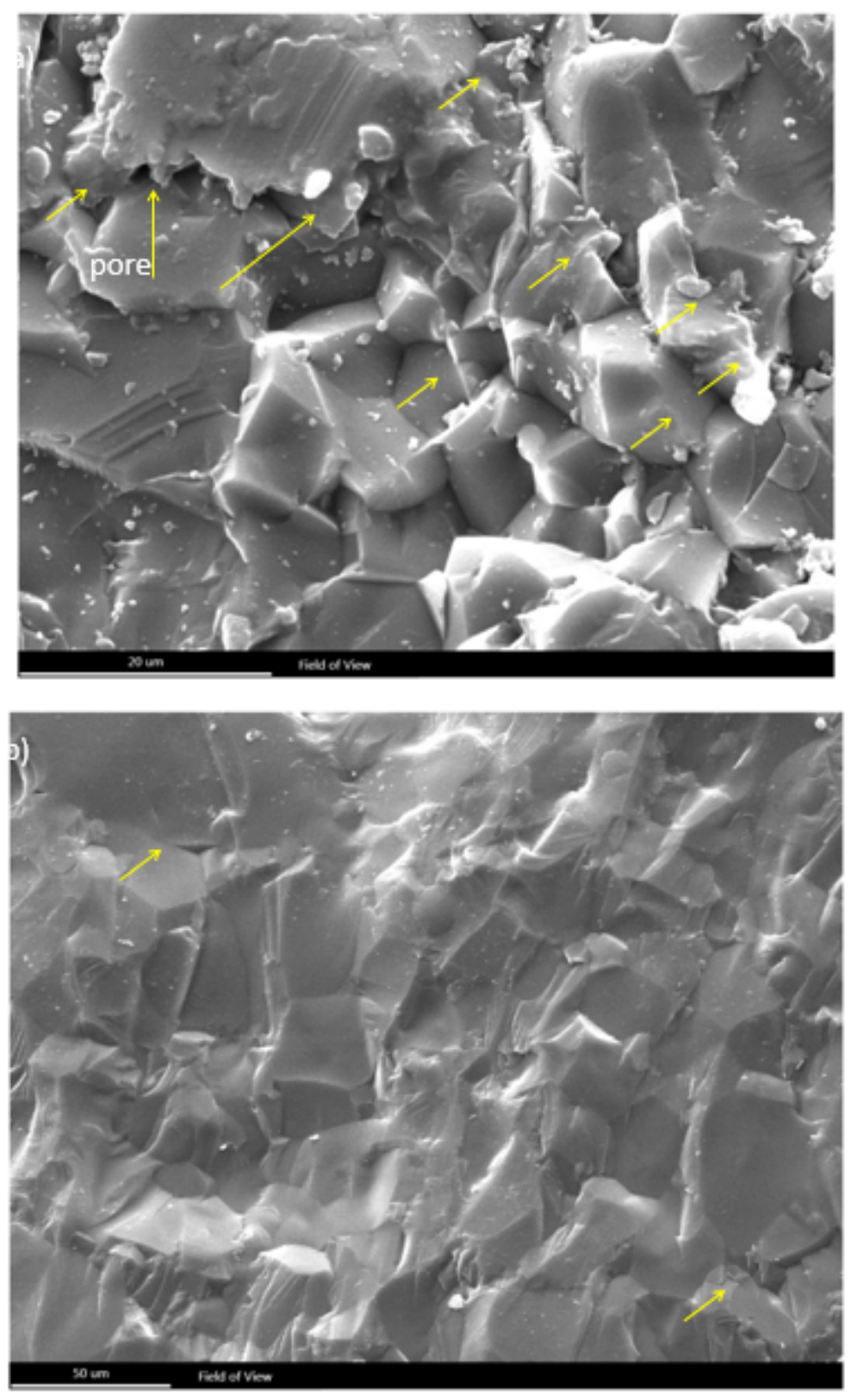

\section{Figure 8}

FE-SEM fracture cross-sectional images of the sintered bulk from the granulated powder at a) $1500^{\circ} \mathrm{C}, \mathrm{b}$ ) $1400^{\circ} \mathrm{C}$. The yellow arrows indicate intergranular porosity. 

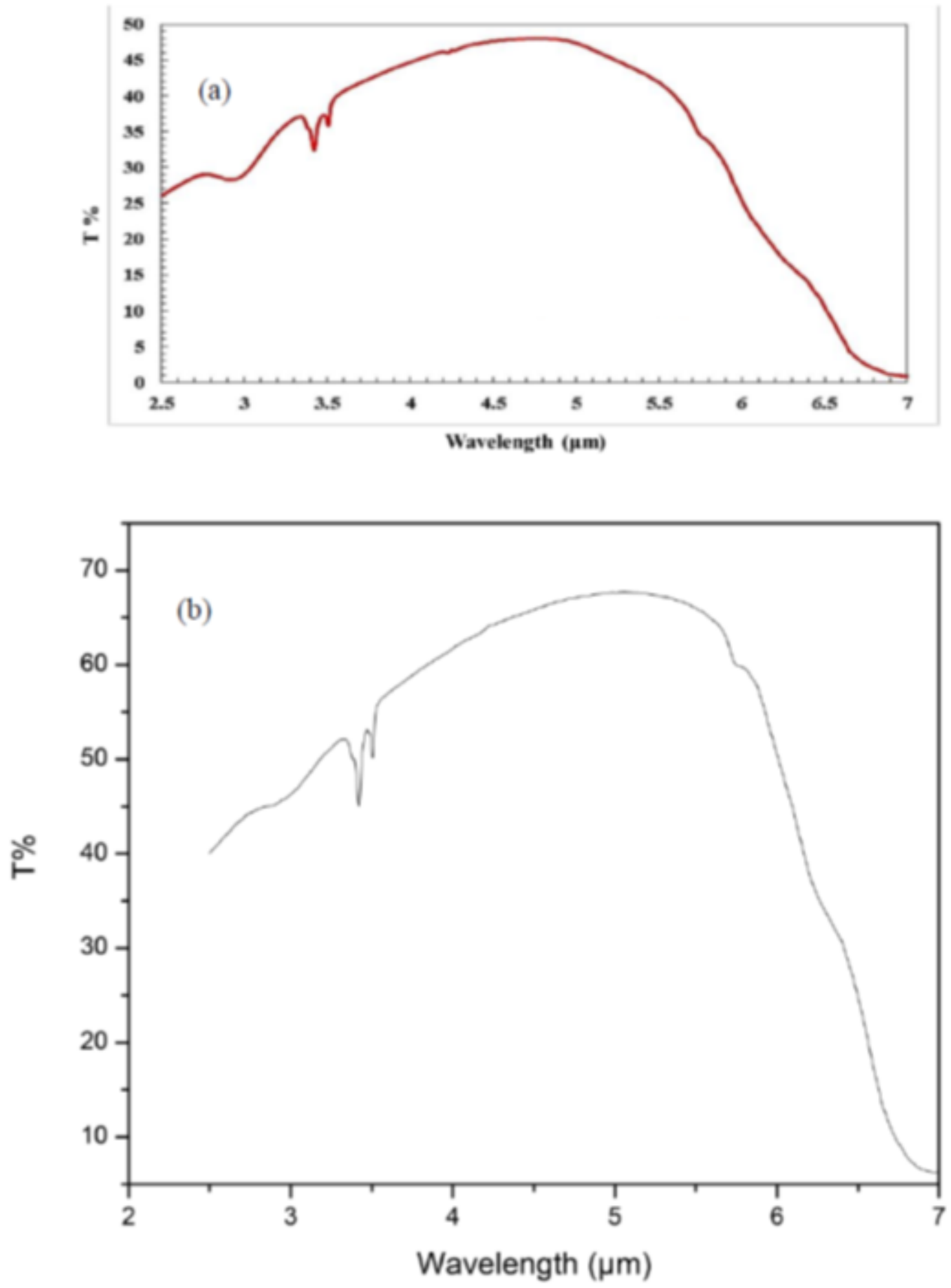

Figure 9

In-line IR transmission diagram of the sintered samples using granulated powder sintered at a) $1500^{\circ} \mathrm{C}$ and b) $1400^{\circ} \mathrm{C}$. 


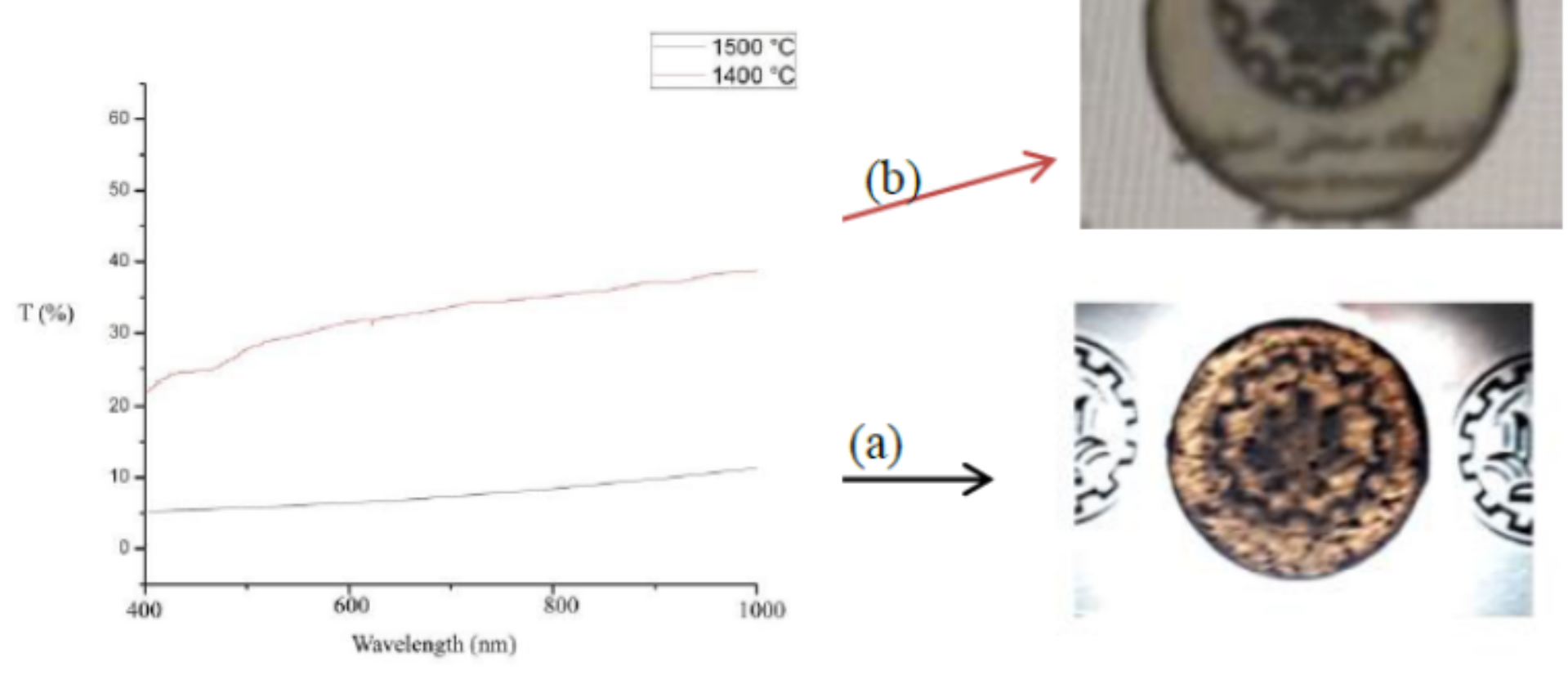

Figure 10

In- line UV-Vis transmission and real image of SPSed sample at temperature of (a) $1500{ }^{\circ} \mathrm{C}$ and (b) 1400 ${ }^{\circ} \mathrm{C}$. Thickness of samples was $4 \mathrm{~mm}$. 

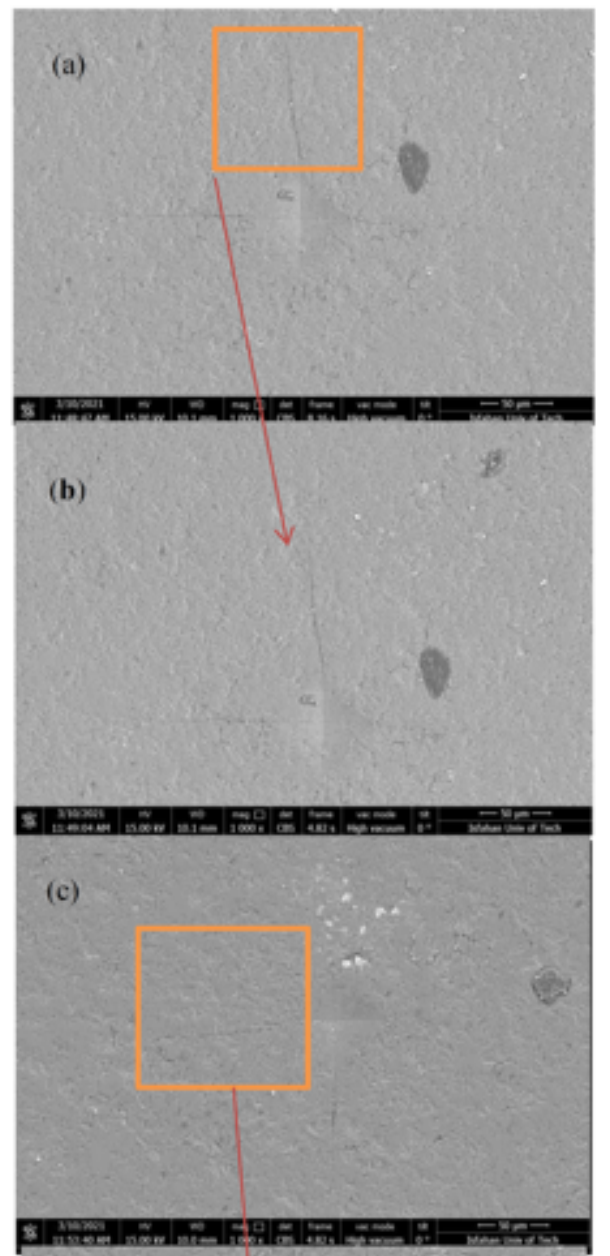

(d)

Figure 11

The effect on Vickers hardness on the samples sintered at a and b) $1400{ }^{\circ} \mathrm{C}, \mathrm{c}$ and d) $1500{ }^{\circ} \mathrm{C}$ 